\title{
Effect of Ascorbic Acid on Food Preference and Consumption in Captive Capybaras (Hydrochoerus hydrochaeris)
}

\author{
Martín Roberto Alvarez* and Fernando Osvaldo Kravetz "In memoriam" \\ Departamento de Ecología, Genética y Evolución; Facultad de Ciencias Exactas y Naturales; Universidad de \\ Buenos Aires, Ciudad Universitaria; Buenos Aires - Argentina. Present address: Departamento de Ciências \\ Biológicas; Universidade Estadual de Santa Cruz; Rodovia Ilhéus/Itabuna, Km. 16; 45662-000; Ilhéus - BA - Brasil
}

\begin{abstract}
The aim of this work was to study the short and long term influences of ascorbic acid on Hydrochoerus hydrochaeris, if supplemented in their food. No differences regarding food intake were observed in the absence of vitamin $C$. On a daily basis, animals accustomed to food containing ascorbic acid prefered to continue eating the same food. Food preference in capybaras did not seem to depend on ascorbic acid availability; however, when accustomed to vitamin $C$, capybaras might recognize and select ascorbic acid in subsequent food. Mechanisms allowing capybaras to "evaluate" the nutritional quality of their food are discussed, as well as the adaptive value of this behavior in free ranging populations.
\end{abstract}

Key words: Vitamin C; Hydrochoeridae; ecophysiology; foraging; nutrition, feeding

\section{INTRODUCTION}

Herbivore diets are extremely complex in the wild, because they often comprise high volumes of lowquality and difficult to digest the foods. Herbivores also face the problem of selecting a balanced diet, not simply maximizing the rate of energy gain (Stephens and Krebs, 1986). These factors are of relevance and may lead herbivores to play a major role in shaping the vegetation community dynamics through selective consumption (Duncan and Gordon 1999; Roguet et al., 1998). Variation in foraging behavior may directly affect digestion (Duncan and Gordon 1999; Shipley et al., 1998). Westorby (1974) found that individuals maximized their diet according to species-specific requirements, but the quality of this choice depended on their ability to detect the particular components in the available diet, and learn the effects of including or avoiding these compounds. Dietary effects usually are not observed immediately, and short and long term learning are required (Westorby 1974).

In mammals that cannot synthesize vitamin C (ascorbic acid), its intake is of paramount importance for the physiological processes (Dabrowski and Ciereszko, 1996; Odumosu and Wilson, 1973; Sato and Udenfriend, 1978).Vitamin C stimulates collagen synthesis, facilitates cell regeneration, lowers cholesterol levels, thus preventing ischaemic heart disease, enhances the absorption of iron and facilitates production of erythrocytes, prevents scurvy, effects reproductive parameters in the males and females of several mammalian species, including man and absorbs free radicals as an antioxidant

\footnotetext{
* Author for correspondence: malva@uesc.br
} 
(Chaterjee et al., 1975; Ficek, 1997; Hand et al., 2000).

Cueto et al. (2000) reported that captive bred capybaras required an exogenous source of vitamin C. Under the experimental diets lacking ascorbic acid, capybaras exhibited symptoms of scurvy: physical distress, gingivitis, loss of incisors, gum and nasal hemorrhages, weakness of joints, fragile bones and, ultimately, death (Cueto et al., 2000). Initial symptoms appeared 25 days after elimination of ascorbic acid in their diet. Ascorbic acid levels also affect strongly the growth and reproduction of captive capybaras (Cueto et al., 2000).

Under natural conditions, capybaras are exclusively herbivorous (González Jiménez and Escobar 1975; Ojasti, 1973; Quintana, 1996), hence, vitamin $\mathrm{C}$ requirements might not affect the survival and reproduction because it is incorporated through the consumption of fresh plant matter. However, certain environmental conditions under which the availability of green forage is reduced, might affect their reproductive success (Cueto et al., 2000).

Because a thorough evaluation of vitamin C content in the natural diet of capybaras has not yet been made, captive conditions are the first step toward testing the relationship between food preferences and a specific nutritional quality of any given food. Thus, an evaluation was needed whether the absence of an essential nutrient, such as vitamin $\mathrm{C}$, might lead to a modification of feeding habits of capybaras. Thus, the aim of this work was to tested if vitamin $\mathrm{C}$ was a major factor in the food selection of captive capybaras. Accordingly, voluntary food consumption and preferences, with and without supplementation of ascorbic acid, as well as the possible influence of such choice on the symptoms of dietary deprivation of vitamin $\mathrm{C}$ was investigated.

\section{MATERIALS AND METHODS}

Experiments were conducted using the management and installations descriptions of Alvarez and Kravetz (2006).
Comparison of voluntary consumption of a commercial food pellet with or without vitamin C supplementation

The experiment was carried out during May and June 1998. Animals $(\mathrm{N}=102)$ were fed ad libitum a diet of commercial food pellets, designed for the rabbits. Nutritional composition was analyzed using AOAC (1984) (Table 1). Water was offered ad libitum. Daily voluntary consumption was calculated as the difference between the offered and remaining food over a 24-h period. Food intake without supplementation was measured for 18 days, after which a vitamin $\mathrm{C}$ supplement (Lascorbic acid, ROVIMIX C ${ }^{\circledR}$, Roche) was added as the only vitamin $\mathrm{C}$ source, mixing $5 \mathrm{~g}$ with the commercial food pellets offered daily to each individual. This amount was calculated according to daily requirements reported for Guinea pigs (Cheeke, 1987) and vitamin C consumption was checked. A 25-day adaptation period to the new diet was carried out before measuring the voluntary food consumption of the enriched formula for additional 18 days.

Comparison of voluntary food intake of mealmixture with or without vitamin $\mathrm{C}$ supplementation

The experiment was carried out offering an ad libitum diet of a meal-mixture composed of corn grain (40\%), alfalfa hay (40\%) and soybean meal (20\%), roughly milled. Only 14 adult capybaras born in captivity were used for this experiment to ensure a strict individual control of food consumption and the welfare of each animal. Chemical composition of this mixture was analyzed using AOAC (1984). Results are presented in Table 1. Water was offered ad libitum. Animals were housed in individual open pens of $3 \times 3 \mathrm{~m}$, without vegetation cover. They were divided randomly into two groups of seven individuals each. Daily voluntary consumption was calculated as previously described. The experiment was divided into two stages:

Stage 1: Group 1 was fed the meal-mixture supplemented with ascorbic acid as described previously. Group 2 was fed the meal-mixture without supplemental vitamin C. Daily voluntary food intake was measured during the following week. 
Stage 2: Following Stage 1, diets were switched between the groups, with Group 2 receiving the meal-mixture with vitamin $\mathrm{C}$ and Group 1 the meal-mixture only. After 14 days (time enough for adaptation to the new diet) the daily voluntary food intake was measured during the seven subsequent days.

Table 1 - Chemical composition of the foods used during the study.

\begin{tabular}{lcc}
\hline Parameters & \multicolumn{2}{c}{ Foods Used } \\
\cline { 2 - 3 } & $\begin{array}{c}\text { Commercial food pellets } \\
(\% \text { of DM) }\end{array}$ & $\begin{array}{c}\text { Meal-mixture } \\
(\% \text { of DM })^{\mathbf{1}}\end{array}$ \\
\hline Moisture (\%) & 13.01 & 13.60 \\
CP & 18.36 & 18.00 \\
TL & 4.80 & 4.00 \\
CF & 12.19 & 18.00 \\
TM. & 7.56 & 6.92 \\
Ca & 0.94 & 0.56 \\
P & 0.57 & 0.40 \\
AA & Traces & Traces \\
\hline
\end{tabular}

Key: $1-\%$ of dry matter; $\mathrm{CP}=$ Crude Protein $\left(\mathrm{N}_{2} \times 6.25\right) ; \mathrm{TL}=$ Total Lipids; $\mathrm{CF}=$ Crude Fiber; $\mathrm{TM}=$ Total minerals; $\mathrm{Ca}=$ Calcium; $\mathrm{P}=$ Phosphorus; $\mathrm{AA}=$ ascorbic acid content.

\section{Evaluation of food preferences with or without vitamin $\mathrm{C}$ supplementation}

Fourteen adult capybaras born in captivity were randomly selected and housed in individual open pens of $3 \times 3 \mathrm{~m}$, without vegetation cover for a "two-pan preference test" (Hand et al., 2000). Animals were divided randomly in two groups of seven individual each. Water was offered ad libitum. The experiment also was divided into two stages. During the first four days (preexperimental stage), Group 1 was fed with mealmixture without supplemented ascorbic acid and Group 2 was fed with meal-mixture plus additional vitamin $\mathrm{C}$ (as described above). During the following four days (second stage), each Group received two pans containing $2 \mathrm{Kg}$ of mealmixture with and without ascorbic acid supplementation, respectively. The position of each pan inside the enclosure was chosen randomly every day. Pans were weighed each day, at regular times, and consumption of each food was calculated by the difference between the initial and final weight of the pan every 24-h, determining food preferences in daily voluntary consumption.

With the goal of measuring short term preferences, this test was repeated, with individuals reassigned to each group, weighing consumption during 3hour periods.

\section{Statistical analysis}

The data did not conform to a normal distribution and equal variances (Sokal and Rohlf, 1981); thus, after non-successful transformations, comparisons were made using non-parametric statistical tests (Siegel and Castellan, 1998). The Mann-Whitney $U$-Test for independent samples was used to compare the voluntary food intake with or without vitamin C (Experiments 1 and 2). Experiments 2 (voluntary consumption in each Group with and without ascorbic acid supplementation) and 3 (food preferences with or without vitamin C addition) were evaluated using the Wilcoxon Matched Pairs Test for dependent samples, considering each individual as a block. Comparisons of consumption between both groups with differences in their previous diets were carried out using the Mann-Whitney $U$-Test. Under the null hypothesis that consumption remains constant along the day, the prospective daily consumption was calculated as food intake after 3-hours x 8, and compared it with the observed daily consumption.

\section{RESULTS}

Voluntary food intake with and without vitamin C supplementation (Experiments 1 and 2)

Significant differences were not observed in any of the variables (Mann-Whitney Test; $\mathrm{U}=50.5 ; \mathrm{Z}=$ 1.242; $p=0.215$; and Mann-Whitney Test; $\mathrm{U}=10$; $\mathrm{Z}=-1.853 ; p=0.084$, respectively) (Table 2). Although six of the seven individuals of each 
group consumed more of the vitamin $\mathrm{C}$ supplemented meal-mixture, significant differences were not observed in daily food intake with $(1.71 \pm 0,47 \mathrm{Kg} /$ day $)$ or without $(1.97 \pm 0,56$ $\mathrm{Kg}$ /day) vitamin $\mathrm{C}$ supplementation (Wilcoxon Matched Pairs Test; $\mathrm{T}=6 ; \mathrm{Z}=1.352 ; p=0.176$ ).

\section{Ascorbic acid preferences (Experiment 3)}

In the long term preferences test, the group that received ascorbic acid during the pre-experimental stage consumed statistically significant more of the supplemented meal-mixture (Wilcoxon Matched Pairs Test; $\mathrm{T}=0 ; \mathrm{Z}=2.366 ; p=0.018$ ) (Table 3). Short term preferences (3-h consumption) with and without vitamin $\mathrm{C}$ supplementation were not detected (Wilcoxon Matched Pairs Test; $\mathrm{T}=7 ; \mathrm{Z}=1.183 ; p=0.237$ and $\mathrm{T}=3 ; \mathrm{Z}=1.860 ; p=0.076$; respectively) (Table 3). Nevertheless, total 3-h food intake was higher in capybaras with pre-experimental vitamin C supplementation (Mann-Whitney Test; $\mathrm{U}=4$; Z $=2.619 ; p=0.008$ ). This group also exhibited a higher food consumption without vitamin $\mathrm{C}$ (Mann-Whitney Test; $\mathrm{U}=2 ; \mathrm{Z}=-2.875 ; p=$ $0.004)$. These differences were not significant when evaluating daily total food intake (Table 3 ). Individuals deprived of supplement during the preexperimental stage showed a daily consumption similar to the previous stage (78.2\%) compared with the other group which consumed less than half the ration $(42.4 \%)$ (Table 4$)$.

\section{DISCUSSION}

Supplementation with vitamin C did not modify daily voluntary food consumption in capybaras breed in captivity (Tables 2 and 3). No reduction of voluntary consumption was detected, as has been reported for Cavia porcellus (Barnes et al., 1973; Kipp et al., 1996; Odumosu and Wilson, 1973). It was reasonable to think that a prolonged (greater than the present study) deprivation of vitamin $\mathrm{C}$ might affect food intake, especially after the first clinical symptoms of scurvy were manifested. For capybaras, this occurred after at least 25 days (Cueto et al., 2000).

Odumosu and Wilson (1973) suggested that a decrease in voluntary consumption of food could contribute to clinical symptoms of scurvy. Present results showed that symptoms of scurvy in capybaras did not support Odumosu and Wilson's (1973) theory for C. porcellus, but rather denoted a lack of vitamin $\mathrm{C}$ in their diet. In spite of vitamin $\mathrm{C}$ being an essential nutrient for capybaras, animals under the experimental conditions do not alter their food consumption dependent upon its presence. However, this may be explained in part by the captive feeding schedules, because an individually based diet with basal supplementation of vitamin C, may allow each animal to forego eventual deprivation without modifying its feeding pattern.

Vitamin $\mathrm{C}$ deprivation time during the preexperimental stages in Experiments 2 and 3 (4 days) was based on the estimates of its physiological elimination rate under sub-clinical or moderate deprivation conditions. Assessing the behavior of captive capybaras under an extreme and chronic absence of ascorbic acid would require an extension of the pre-experimental stage for at least 25 days, to include any physiological variable that might influence on the normal elimination of a daily supplementation of ascorbic acid. After the establishment of clinical symptoms of scurvy, a decrease in voluntary consumption and food preferences were expected, related to a "physiological hunger" (Westorby, 1974) for ascorbic acid.

From the results of food preference experiments (Experiment 3), it could be concluded that, if preaccommodated to vitamin $\mathrm{C}$, capybaras might recognize and select the food containing ascorbic acid. Previous experience seemed to influence the acceptance of food, daily feeding patterns and food preferences. On a daily basis, animals used to food containing ascorbic acid preferred to continue eating the same food. This was reflected by the highest daily consumption of food with vitamin $\mathrm{C}$ observed in animals that consumed the supplemented food during the pre-experimental stage (Table 3).

Perception of nutrients in a diet may be facilitated via two mechanisms: (1) immediate sensory (flavor, color, scent, texture), and, (2) due to postfeeding effects of nutritional content (Hand et al., 2000). The first mechanism, relates to short term recognition, involving a pre-ingestion mechanism (Villalba and Provenza, 1999); the second is considered long term recognition, because it involves the time required for digestion (Duncan and Gordon, 1999).

Results showed that capybaras did not show shortterm preferences (Table 3), indicating that recognition of ascorbic acid might occur at some time after the 3-h intervals. A pre-ingestion 
mechanism or "specific appetite" towards vitamin $\mathrm{C}$ seemed unlikely, indicating a possible postingestion mechanism. Although a more specific design is needed to clarify short term preferences, it is traditionally understood that herbivores might not detect specific components of their diets, besides sodium and water (Stephens and Krebs, 1986).

Table 2 - Voluntary daily food intake ( $\mathrm{Kg} /$ day) of commercial pellet and meal-mixture with or without supplemented vitamin C.

\begin{tabular}{cccc} 
& \multicolumn{3}{c}{ Daily Food Intake (Kg/day) $^{\mathbf{1}}$} \\
\cline { 2 - 4 } Experiment $^{2}$ & Food tested & With Vitamin C & Without Vitamin C $^{$\cline { 2 - 3 } 2$}$ \\
\hline 1 & Commercial pellet & $92.60 \pm 3.44(18)$ & $87.86 \pm 1.72(18)$ \\
& Meal-mixture & $2.300 \pm 0.559(4)$ & $1.968 \pm 0.461(4)$
\end{tabular}

Key: 1- Data expressed as Mean \pm 1 Standard Deviation $(n=$ days), no statistical differences were observed according to MannWhitney Test. 2- Experiment 1: 102 individuals (whole population), Experiment 2 (second stage): Groups 1 and 2 consisted of 7 individuals each.

Table 3 - Results of Experiment 3: short term (3 hours) and long term (24 hours) food preferences with or without (W/O) vitamin $\mathrm{C}$, related to the pre-experimental diet with or without supplemented vitamin $\mathrm{C}$.

\begin{tabular}{|c|c|c|c|}
\hline & \multicolumn{3}{|c|}{ Voluntary Food Intake $(\mathrm{Kg})^{1}$} \\
\hline & $\begin{array}{c}\text { Treatment } \\
\text { WITH Vit. C }\end{array}$ & $\begin{array}{l}\text { Treatment } \\
\text { W/O Vit. C }\end{array}$ & TOTAL \\
\hline \multicolumn{4}{|l|}{ Short term preferences } \\
\hline $\begin{array}{l}\text { Group 1: Pre-experimental diet With } \\
\text { Vitamin C }\end{array}$ & $0.540 \pm 0.270$ & $0.631 \pm 0.243^{\mathrm{a}}$ & $1.171 \pm 0.347^{\mathrm{a}}$ \\
\hline $\begin{array}{l}\text { Group 2: Pre-experimental diet Without } \\
\text { Vitamin C }\end{array}$ & $0.348 \pm 0.297$ & $0.267 \pm 0.102^{b}$ & $0.614 \pm 0.234^{b}$ \\
\hline Long term preferences & & & \\
\hline $\begin{array}{l}\text { Group 1: Pre-experimental diet With } \\
\text { Vitamin C }\end{array}$ & $2.336 \pm 0.333^{c}$ & $1.890 \pm 0.304^{\mathrm{d}}$ & $4.163 \pm 0.876$ \\
\hline $\begin{array}{l}\text { Group 2: Pre-experimental diet Without } \\
\text { Vitamin C }\end{array}$ & $1.823 \pm 0.367$ & $1.493 \pm 0.660$ & $3.450 \pm 0.705$ \\
\hline
\end{tabular}

Key: 1- Values of consumption $(\mathrm{Kg})$ are presented as the Mean \pm 1 standard deviation; $\mathrm{n}=7$ (individuals in each group). Different letters means significant differences $(\mathrm{p}<0.05)={ }^{\mathrm{a}-\mathrm{b}}$ : between groups according to Mann-Whitney U-test; ${ }^{\mathrm{c}-\mathrm{d}}$ : between treatments according to Wilcoxon Matched Pairs Test.

Table 4 - Daily Food Intake (Kg/day) according to pre-experimental diet with or without supplemented vitamin C. Evaluation of the null hypothesis: consumption remains constant along the day.

\begin{tabular}{lcc}
\hline & \multicolumn{2}{c}{ Mean Daily Food Intake (Kg/day) } \\
\cline { 2 - 3 } Expected Food Intake after 24 hs ${ }^{\mathbf{1}}$ & With Vitamin C & Without Vitamin C \\
Observed Food Intake after 24 hours & 9.368 & 4.912 \\
\%Variation = Observed x 100/ Expected & 4.163 & 3.450 \\
\hline
\end{tabular}

Key: 1- Expected daily food intake (Kg/day) = Food intake observed after 3-hours x 8. 
Studies with cattle and sheep has shown that these animals can choose among commercial foods that allow them to maximize growth, with the selection mechanism governed by "post-ingestion effect" (post-ingestion feedback), allowing the animal to select the optimal diet through evaluation of nutritional quality of a particular food (Duncan and Gordon, 1999). Apparently sheep has the capacity to discriminate through post-ingestion effects, both energy and protein obtained from each food, and then associate that effect to specific flavors of that food (Villalba and Provenza, 1999). It has also been reported that sheep moves physically towards any given food for a distance directly proportional to the nutritional benefit obtained from that particular item (Roguet et al., 1998).

Under natural conditions, elements associated with vitamin $\mathrm{C}$ content might allow capybaras to recognize its presence in their food. It may also allow capybaras to remember benefits and digestive problems, and to associate them with intake of a particular food, and subsequently select or reject it. In this work it was observed that feeding patterns of capybaras were affected by ascorbic acid in their diets. While total daily consumption of food was not modified by the intake of this nutrient, short term consumption (in the 3-h range) was higher in the group that received vitamin $\mathrm{C}$ (Table 3). In capybaras habituated to ascorbic acid, consumption after 3-h represented $28.1 \%$ of the total daily consumption, while for the other group, it was only a $17.2 \%$. This could be considered an evidence of higher general activity of the best nurtured capybaras during the first hours post-fast.

The potential response of wild capybaras to low habitat quality could be inferred from the present results with captive individuals. Would capybaras living in low quality habitats benefit from immediate consumption of large amounts of fresh foliage (rich in vitamin C), rather than investing energy toward defense of this resource from intragroup competitors? Because vitamin $\mathrm{C}$ might be considered an indicator of environmental quality (Cueto, 1999), rapid consumption of food rich in vitamin C (as was observed in this study) may be highly adaptive for wild individuals. Such behavior would improve their physical condition and facilitate the avoidance of potentially agonistic behaviors in defense of the resource. Marked stable social hierarchies exist among both wild and captive bred capybaras, with a dominant individual having access to the best resources, and resulting in higher fitness expressed as a greater number of offspring (Cueto, 1999; Herrera and MacDonald, 1987, 1993; Nogueira et al., 1999; Yaber and Herrera, 1994). A better nurtured animal has an advantage when finding high quality food, and will be better prepared to rapidly consume it, thus improving the physical condition and social status. Such behavior would be under positive selection, and may influence the population dynamics by conferring an edge to intra-population competitors. It could be concluded that capybaras did not generally consume more food when it was supplemented with ascorbic acid. However, when pre-accommodated to vitamin $\mathrm{C}$, they showed a significant preference towards the vitamin C supplemented food. Moreover, this preference seemed mediated through long-term recognition, suggesting that post feeding selection (explained by physiological variables related to ascorbic acid metabolism) was fundamental to food preference and consumption in capybaras.

\section{ACKNOWLEDGEMENTS}

The animals used in this experiment were handled humanely at all times; the Capybara farm was supervised by the ethics committee of the INTA to ensure animal welfare. The authors wish to express their gratitude to Roberto Aranda for field assistance. We are grateful to J. Adrian Monjeau, Francisco Bozinovic and Romari A. Martinez for helpful comments and critical review of the manuscript. Many thanks to Carl W. Dick and anonymous reviewer for help with the final english version and improvements in the manuscript. Marcelo Paolella from Roche S.A. donated the Rovimix $C$ ( supported by the Consejo Nacional de Investivaciones Científicas y Tecnológicas (CONICET, Argentina) and by the Universidad de Buenos Aires (UBA, Argentina).

\section{RESUMO}

O ácido ascórbico é um nutriente essencial para as capivaras (Hydrochoerus hydrochaeris). No presente trabalho foi avaliado o efeito do ácido ascórbico sobre o consume e as preferências alimentares a curto e longo prazo, assim como a 
influencia da escolha sobre a sintomatologia da carência de vitamina $\mathrm{C}$ na dieta. Não foram observadas diferencias no consumo de alimento na ausência deste nutriente. Considerando as preferências a longo prazo (24h), os animais acostumados a consumir vitamina $\mathrm{C}$ continuavam consumindo preferencialmente $\mathrm{o}$ alimento suplementado. As preferências alimentares em capivaras não parecem depender da disponibilidade de ácido ascórbico; no entanto, quando acostumados à vitamina $\mathrm{C}$, estes animais podem reconhecer e selecionar o ácido ascórbico na alimentação subseqüente. São discutidos os mecanismos que permitem as capivaras "avaliar" a qualidade nutricional do alimento, assim como o valor adaptativo destes comportamentos em populações silvestres.

\section{REFERENCES}

Alvarez, M. R., Kravetz, F. O. (2006), Reproductive performance of capybaras (Hydrochoerus hydrochaeris) in captivity under different management systems in Argentina. Anim. Res., 55, 153-164.

AOAC. (1984), Official Methods of Analysis of the Association of Official Analytical Chemists. 14th Ed. Association of Official Analytical Chemists, D.C.

Barnes, M. J., Constable , B. J., Impey, S. G., Kodicek, E. (1973), Mortality rate in male and female guineapigs on a scorbutogenic diet. Nature, 242, 522-523.

Chaterjee, I. B., Majumder, A. K., Nandii, B. K., Subramanian, N. (1975), Synthesis and some major functions of vitamin $\mathrm{C}$ in animals. Annals NY Acad Sci., 258, 24-27.

Cheeke, P. R. (1987), Alimentación y nutrición del conejo. Editorial Acribia S.A. Zaragoza, Spain.

Cueto, G. R. (1999), Biología reproductiva y crecimiento del carpincho (Hydrochoerus hydrochaeris) en cautiverio: Una interpretación de las estrategias poblacionales. $\mathrm{PhD}$ Thesis, Universidad de Buenos Aires, Buenos Aires, Argentina.

Cueto, G. R., Allekotte, R., Kravetz, F. O. (2000), Scurvy in capybaras bred in captivity in Argentine. $J$ Wildlife Dis., 36, 97-101.

Dabrowski, K., Ciereszko, A. (1996), Ascorbic acid protects against male infertility in a teleost fish. Experientia, 52, 97-100.

Duncan, A. J., Gordon, I. J. (1999), Habitat selection according to the ability of animals to eat, digest and detoxify foods. P Nutr Soc., 58, 799-805.
Ficek, W. (1997), Biological importance of vitamin C in the bodies of mammals. Biochem Arch., 13, 207213.

González Jiménez, E., Escobar, A. (1975), Digestibilidad comparada entre chigüires (Hydrochoerus hydrochaeris), conejos y ovinos con raciones de diferentes proporciones de forrajes y concentrados. Agronomía Tropical, 25, 283-290.

Hand, M. S., Thatcher, C. D., Remillard, R. L., Roudebush, P. (2000), Small animal clinical nutrition. Walsworth Publishing Company, Missouri, USA.

Herrera, E. A., MacDonald, D. W. (1987), Group stability and the territoriality in group-living capybaras (Hydrochoerus hydrochaeris). J Anim Ecol., 58, 667-679.

Herrera, E. A., MacDonald, D. W. (1993), Aggression, dominance, and mating succes among capybara males (Hydorchaeris hydrochaeris). Behav Ecol., 4, 114119.

Kipp, D. E., Mcelvain, M., Kimmel, D. B., Akhter, M. P., Robinson, R. G., Lukert, B. P. (1996), Scurvy results in decreased collagen synthesis and bone density in the guinea pig animal model. Bone, 18, 281-288.

Nogueira, S., Nogueira-Filho, S., Otta, E., Dias, C., Carvalho, A. (1999), Determination of infanticide causes in capybara (Hydrochaeris hydrochaeris) groups in captivity. Appl Anim Behav Sci., 62, 351357.

Odumosu, A., Wilson, C. W. (1973), Metabolic availability of vitamin $\mathrm{C}$ in the guinea-pig. Nature, 242, 519-521.

Ojasti, J. (1973), Estudio biológico del chigüire o capibara. Editorial Sucre. Caracas, Venezuela.

Quintana, R. D. (1996), Análisis y evaluación de la aptitud de hábitat del carpincho (Hydrochaeris hydrochaeris) en relación con la heterogeneidad del paisaje y las interacciones con ganado doméstico. PhD Thesis, Universidad de Buenos Aires, Buenos Aires, Argentina.

Roguet, C. H., Dumontand, B., Prache, S. (1998), Selection and use of feeding sites and feeding stations by herbivores: A review. Ann Zootech Paris, 47, 225244.

Sato. P., Udenfriend, S. (1978), Scurvy-prone animals, including man, monkey, and guinea pig, do not express the gene for gulonolactone oxidase. Arch Biochem Biophys., 187, 158-162.

Shipley, L. A., Blomquist, S., Danell, K. (1998), Diet choices made by free-ranging moose in northern Sweden in relation to plant distribution, chemistry, and morphology. Can J Zool., 76, 1722-1733. 
Siegel, S., Castellan, N. J. (1998), Estadística no paramétrica aplicada a las ciencias de la conducta. Editorial Trillas. México D.F., Mexico.

Sokal, R. R, Rohlf, F. J. (1981), Biometry: The principles and practice of statistics in biological research. W.H. Freeman and Co., San Francisco, USA.

Stephens, D. W., Krebs, J. R. (1986), Foraging Thoery. Monographs in Behavior and Ecology. Princeton University Press. New Jersey, USA.

Villalba, J. J., Provenza, F. D. (1999), Nutrient-specific preferences by lambs conditioned with intraruminal infusions of starch, casein, and water. Anim Sci., 77, 378-387.
Westorby, M. (1974), An analysis of diet selection by large generalist herbivores. Am Nat., 108, 290-304.

Yaber, M. C., Herrera, E. A. (1994), Vigilance, group size and social status in capybaras. Anim Behav., 48, 1301-1307.
Received: May 31, 2007; Revised: December 05, 2007; Accepted: April 24, 2008 